\title{
Distribution of coral reef fishes along a coral reef-seagrass gradient: edge effects and habitat segregation
}

\author{
Martijn Dorenbosch, Monique G. G. Grol, Ivan Nagelkerken*, Gerard van der Velde \\ Department of Animal Ecology and Ecophysiology, Institute for Wetland and Water Research, Radboud University Nijmegen, \\ Toernooiveld 1, 6525 ED Nijmegen, The Netherlands
}

\begin{abstract}
Coral reefs and seagrass beds are often located adjacent to one another, but little is known about the degree to which their fish communities are interlinked. To determine whether coral reef fishes on the coral reef are interlinked with or segregated from fishes on adjacent seagrass beds, a $60 \mathrm{~m}$ coral reef-seagrass gradient was studied on the island of Zanzibar in the western Indian Ocean. Using underwater visual census, coral reef fishes were surveyed in 4 habitat zones: (1) a coral patch reef, (2) seagrass beds bordering the coral reef, (3) seagrass beds at a $30 \mathrm{~m}$ distance from the coral reef edge and (4) seagrass beds at a $60 \mathrm{~m}$ distance from the coral reef edge. Based on the densities of juveniles and adults in the 4 zones, the 48 species that were observed were classified into reef-associated species, seagrass-associated species, nursery species, generalists and rare species. Reef-associated species occurred almost exclusively on the coral reef and at the reef-seagrass edge, while seagrass-associated species occurred almost exclusively on the seagrass beds. Generalists and seagrass-associated species occurred in all 3 seagrass zones, but densities of generalists on seagrass beds decreased with increasing distance from the reef, whereas that of seagrass-associated species increased. Reef-associated and generalist species showed an edge effect, where densities on the seagrass beds near the reef edge were higher than on the seagrass beds further away. Juvenile densities of nursery species on seagrass beds also increased with the distance from the reef, whereas their adults showed the highest densities on the coral reef, suggesting a possible ontogenetic shift from the seagrass beds to the reef. The results of the present study show that this seagrass-coral reef landscape features habitat segregation between species and life stages and shows an edge effect, possibly driven by competition mechanisms between species or life stages.
\end{abstract}

KEY WORDS: Coral reef fish - Seagrass beds - Habitat connectivity - Species interaction · Migrations · Edge effect Resale or republication not permitted without written consent of the publisher

\section{INTRODUCTION}

Many coral reef fish use seagrass beds either as a nursery habitat or as a feeding or resting habitat (Parrish 1989, Baelde 1990, Blaber 2000, Beck et al. 2001). Although the utilisation of seagrass beds by reef fish has been extensively studied, fewer studies have focused on the interlinkages between fish communities of seagrass beds and coral reefs (Sale 2002). In the present study, these interlinkages are defined as functional processes where fish communities between habitats influence each other, i.e. by direct mechanisms such as migrations of individuals or indirect mechanisms such as predation or competition. Studies that have described such direct interlinkages have considered only ontogenetic migrations (Rooker \& Dennis 1991, Appeldoorn et al. 1997, Nagelkerken et al. 2000a,b, Cocheret de la Morinière et al. 2002, Mumby et al. 2004, Nakamura \& Sano 2004a) or daily feeding migrations (Ogden \& Buckman 1973, Ogden \& Ehrlich 1977, Weinstein \& Heck 1979, Baelde 1990, Kochzius 1997) as functional processes that structure fish communities in the 2 habitats. 
The few studies that have examined interlinkages between multiple fish species on seagrass beds and coral reefs were carried out in situations where the 2 habitat types were located at some distance (i.e. hundreds of metres) from each other. This distance may be too large to result in species interactions between these habitats, because species associated with 1 habitat may only migrate across short distances (metres) to adjacent habitats. No published studies seem to have investigated fish species distribution patterns in a continuous reef-seagrass gradient.

Where coral reefs and seagrass beds meet, interactions between fish communities associated with 1 of these habitats are very likely to occur in the edge zone: reef-associated fish may partly migrate into the seagrass beds, whereas seagrass-associated fish may partly migrate onto the reef. Although migration of individuals can directly influence the structure of fish communities in these habitats, interactions between species such as predation or competition for food and space may also have a strong effect on the structure of these fish communities. Depending on the underlying mechanisms, the transition of coral reef into seagrass beds may therefore result in an 'edge effect' where species show increases, decreases or no change in abundance (Ries \& Sisk 2004). Sweatman \& Robertson (1994) and Shulman (1985) showed that predation by reef-associated fish influenced the occurrence of juvenile grunts and surgeonfishes on seagrass beds directly bordering the reef in a short reef-seagrass gradient. In various coral-dwelling reef fish species that co-exist on a small spatial scale, competition appears to influence habitat selection (Eagle et al. 2001, Munday et al. 2001, Clarke \& Tyler 2003, Webster 2004). It is therefore possible that the fish communities of the 2 habitats interact with each other at the edge of each habitat, giving rise to an edge effect, which results in habitat segregation, possibly driven by competition or predation.

In the present study, it was hypothesised that the composition of reef fish species on seagrass beds would change with increasing distance from the coral reef. Species that are mainly reef-associated were expected to dominate the fish community on the reef and perhaps also the reef-seagrass edge, whereas seagrass-associated species were expected to dominate the entire seagrass bed. On a $60 \mathrm{~m}$ coral reefseagrass gradient, we examined the distribution of various coral reef fish species to answer the following questions: (1) do fishes from the coral reef use adjacent seagrass beds as a habitat, (2) do densities of fish species on the seagrass bed change with increasing distance from the reef and (3) how are densities of different fish species related to each other along this gradient?

\section{MATERIALS AND METHODS}

Study area. The present study was done on a continuous coral reef-seagrass gradient situated at the entrance of Chwaka Bay, a shallow marine bay on the east coast of the island of Zanzibar (Tanzania) in the western Indian Ocean (Fig. 1). This bay was characterised by large areas of mangrove forest, mudflats and seagrass beds. There are no rivers that discharge in this area. At the entrance of the bay, at an average depth of $11 \mathrm{~m}, 3$ patch reefs were present (Fig. 1) which directly bordered uniform monospecific seagrass beds with a $100 \%$ coverage of Thalassodendron ciliatum. The width of the seagrass beds varied between 80 and $250 \mathrm{~m}$, beyond which there were seabeds of bare pebbles or sand. The lengths of the patch reefs varied between 300 and $800 \mathrm{~m}$, with a width of about $100 \mathrm{~m}$. No halos of reduced seagrass cover (as described for the Caribbean by Ogden et al. 1973 and Hay 1984) were present at the reef-seagrass

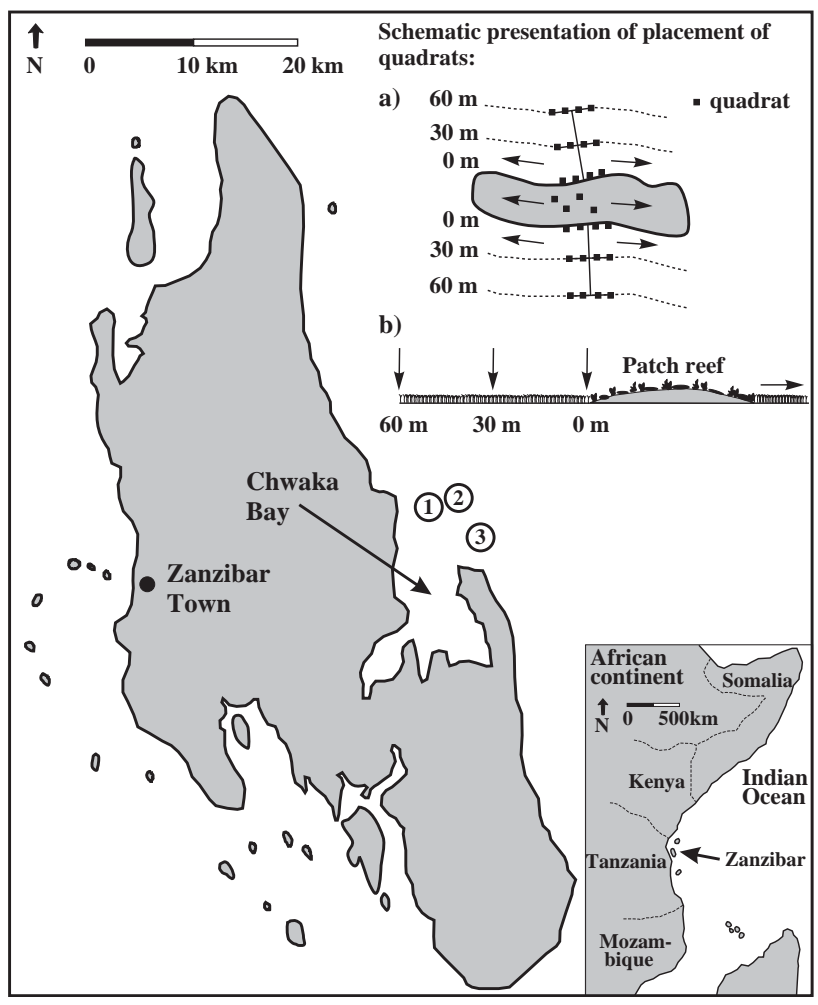

Fig. 1. Overview of the study area (geographic location of Zanzibar island: latitude $6^{\circ} 10^{\prime} \mathrm{S}$, longitude $39^{\circ} 10^{\prime} \mathrm{E}$ ) and locations of the 3 sampled patch reef-seagrass gradients. A schematic presentation of the placement of quadrats in each habitat zone (coral reef, $0 \mathrm{~m}$ seagrass zone, $30 \mathrm{~m}$ seagrass zone and $60 \mathrm{~m}$ seagrass zone) is shown in (a) overview and (b) cross section. Numbers 1-3 indicate the locations of the 3 sampled patch reefs 
edges. The 3 patch reefs all had a comparable coral complexity (mean coral cover $48.5 \% \pm 25.7$; mean maximum coral height $1.0 \mathrm{~m} \pm 0.4$ ) and were not influenced by other nearby coral reefs (distance to the nearest coral reef was $5.0 \mathrm{~km}$ ).

Field sampling and study design. To study the distribution of coral reef fishes within this reef-seagrass gradient, 4 habitat zones were distinguished: the coral reef and 3 seagrass zones located at increasing distances from the coral reef $(0,30$ and $60 \mathrm{~m}$ from the coral reef). A selection of the complete fish community in each habitat zone was surveyed by means of underwater visual census using SCUBA and a stationary point-count method (Watson \& Quinn 1997, Polunin \& Roberts 2004). Fish species were selected based on our ability to identify them during underwater visual census, as well as on their commercial value for fisheries (Jiddawi \& Stanley 1997). All species belonging to the Haemulidae, Lethrinidae, Lutjanidae, Mullidae, Nemipteridae, Scaridae and Siganidae families were included, as were 2 species of Acanthuridae (Acanthurus leucosternon and Naso unicornis), 2 Chaetodontidae species (Chaetodon mellanotus and C. auriga), 3 largesized Labridae species (Cheilinus trilobatus, C. undulatus and Cheilio inermis) and 1 Zanclidae species (Zanclus cornutus).

Because underwater visibility ranged from 6 to $10 \mathrm{~m}$, $5 \times 5 \mathrm{~m}$ quadrats were surveyed. Visual census surveys in the coral reef zone were performed at the centre of the patch reef, at a minimum distance of $15 \mathrm{~m}$ from the edge of the reef. Within the centre of the patch reef, quadrats were randomly placed with a minimum distance of $20 \mathrm{~m}$ between each other. A total of 45 quadrats were surveyed, divided over the 3 patch reefs: 20 quadrats on patch reef 1, 14 on reef 2 and 11 on reef 3 (for patch reef numbers see Fig. 1). The number of quadrats that was surveyed on each patch reef depended on the size of the patch reef. To survey quadrats on the seagrass beds, the distance to the coral reef was determined by placing a $60 \mathrm{~m}$ quadrat line perpendicular to the edge of the coral reef (see Fig. 1 for a schematic presentation of placement of quadrats). Visual census surveys were done at $0-5 \mathrm{~m}, 30-35 \mathrm{~m}$ and $60-65 \mathrm{~m}$ from the reef (hereafter referred to as the $0 \mathrm{~m}, 30 \mathrm{~m}$ and $60 \mathrm{~m}$ seagrass zones). Seagrass quadrats bordering the reef started where the reef ended and did not include any corals. At each side of the $60 \mathrm{~m}$ quadrat line, 2 quadrats were surveyed in each of the 3 seagrass zones (Fig. 1). The minimum distance between 2 quadrats on the seagrass beds was $20 \mathrm{~m}$. After the 3 seagrass zones (i.e. 12 quadrats) had been surveyed for the first time, the quadrat line was shifted over a distance of $100 \mathrm{~m}$ and the survey was repeated in a similar way as the first time. This procedure was done 2 to 4 times per patch reef, depending on its size.
A total of 34 quadrats were surveyed in the $0 \mathrm{~m}$ seagrass zone (8 along patch reef 1, 10 along reef 2 and 16 along reef 3$), 34$ in the $30 \mathrm{~m}$ seagrass zone (12 along patch reef 1, 6 along reef 2 and 16 along reef 3 ) and 32 in the $60 \mathrm{~m}$ seagrass zone (10 along patch reef 1,6 along reef 2 and 16 along reef 3 ). The number of surveyed quadrats per zone in each patch reef gradient differed because sometimes patches of sand or pebbles interrupted the seagrass beds surrounding the patch reef.

Visual census data were collected by 2 observers who independently surveyed quadrats that were randomly allocated to the observers. On the seagrass beds all quadrats to the left of the $60 \mathrm{~m}$ quadrat line were allocated to 1 observer and at the same time all of the quadrats to the right were allocated to the other observer.

A $5 \mathrm{~m}$ rope was used as a reference for quadrat size. After placing the line, the observer waited $3 \mathrm{~min}$ to minimise fish disturbance. All target species within or passing through the quadrat were then counted within a period of $10 \mathrm{~min}$. During the first $7 \mathrm{~min}$, the observer was situated on the edge of the quadrat, while during the last 3 min the observer moved over the quadrat to search for small juvenile fish possibly hiding behind corals or seagrass leaves. Care was taken not to count individuals or groups of fish that regularly moved in and out the quadrat more than once. When surveying the $0 \mathrm{~m}$ seagrass zone, extra care was taken to only count fishes that were really present within the borders of the seagrass quadrat. Fish were classified into $2.5 \mathrm{~cm}$ size classes using an underwater slate. Surveys were conducted between 07:00 and 14:00 h at high or low tide, when water movement was minimal. To minimize observer effects, species identification and quantification were first thoroughly practiced simultaneously by the 2 observers until their results were comparable. The observers were trained to estimate size classes before the start of the study by repeatedly estimating the sizes of 50 pieces of electrical wire of known length and representing all fish size classes, placed at random underwater. Training was continued until differences in size estimation were minimal (i.e. a deviation of no more than $\pm 2.5 \mathrm{~cm}$ from the actual length for objects $<20 \mathrm{~cm}$ ). Visual census data were collected during $10 \mathrm{~d}$ in January 2004. This period falls within the middle of the northeast monsoon when rainfall is limited and water temperatures are high. Salinity and temperature are relatively constant during this time of the year and little temporal variation in fish assemblages was expected.

Because seagrass habitat complexity can influence fish densities (Sogard et al. 1987, Hyndes et al. 2003), shoot density and seagrass height were measured in each of the 3 seagrass zones at the locations where the 
fish quadrats were surveyed. Mean seagrass height was quantified by measuring the length (to the nearest $\mathrm{cm}$ ) of both the shoot and leaf of 40 seagrass plants in each seagrass zone that were randomly selected in the 3 patch reef-seagrass gradients. Mean shoot density of each seagrass zone was estimated by counting the number of shoots in $50 \times 50 \mathrm{~cm}$ quadrats (taking 10 replicate measurements per seagrass zone, randomly placed in the 3 patch reef-seagrass gradients).

Data analysis. Mean seagrass height and shoot density were compared between the 3 seagrass zones using 1-way ANOVA. A non-parametric Spearman rank correlation was performed to determine the relationship between mean seagrass height and shoot density on the 3 seagrass zones.

Fish counts of all individual quadrats collected by visual census in the 3 patch reef-seagrass gradients were used as replicates. Similarity in fish assemblage structure between the 4 different habitat zones was compared using cluster analysis of fish species densities (with all size classes pooled), using the BioDiversity Pro computer program (McAleece 1997) on the basis of Euclidean distances and using group average linkage.

Fish were recorded as juveniles when they were smaller than $1 / 3$ of the maximum species length (Nagelkerken \& van der Velde 2002). Maximum lengths of species were obtained from FishBase World Wide Web (Froese \& Pauly 2003). Specimens of species with a maximum length $>90 \mathrm{~cm}$ were recorded as juveniles when they were $<30 \mathrm{~cm}$. For those species for which the maturation size was known, the one-third-ofmaximum-length rule was found to be suitable to define juveniles. This was tested for Chaetodon auriga, Chlorurus sordidus, Lethrinus lentjan, L. nebulosus, Lutjanus fulviflamma, L. lutjanus, Parupeneus macronema and Scarus psittacus.

Based on the density distribution of juveniles and adults of the observed fish species along the coral reef-seagrass gradient, species were classified into seagrass residents, nursery species, reef residents, generalists and rare species (according to criteria listed in Table 1). The term nursery species is used to describe species that show high juvenile densities on the seagrass beds and low densities on the coral reef, and of which the adults show the opposite pattern and are mainly concentrated on the reef. In the present study, the term nursery species does not imply that seagrass beds function as a nursery habitat per se (as defined in Beck et al. 2001).

The criteria that were used here to classify species into the 5 groups were arbitrarily chosen. To check this classification, principal component analyses (PCA) was performed on the distribution of juveniles and adults of the observed species in the 4 habitat zones (rare
Table 1. Criteria used to categorise species into 5 different groups. JD: mean juvenile density on either the coral reef (based on all coral reef quadrats, reef) or seagrass (based on all seagrass quadrats. sg); SJD: sum of JD on the coral reef and seagrass; $\mathrm{AD}$ : mean adult density on either the coral reef or seagrass; $\mathrm{SAD}$ : sum of $\mathrm{AD}$ on the coral reef and seagrass

\begin{tabular}{|c|c|c|}
\hline $\begin{array}{l}\text { Species } \\
\text { group }\end{array}$ & $\begin{array}{l}\text { Juvenile density } \\
\text { (\% of SJD) }\end{array}$ & $\begin{array}{l}\text { Adult density } \\
\text { ( } \% \text { of SAD) }\end{array}$ \\
\hline Seagrass residents & $>70, \mathrm{sg}$ & $>70, \mathrm{sg}$ \\
\hline Nursery species & $>70, \mathrm{sg}$ & $>70$, reef \\
\hline Generalists & 30 to $70, \mathrm{sg}$ & 30 to $70, \mathrm{sg}$ \\
\hline Reef residents & $>70$, reef & $>70$, reef \\
\hline Rare species & \multicolumn{2}{|c|}{$\begin{array}{l}\text { Total fish density }<0.25 \text { individuals } \\
100 \mathrm{~m}^{-2} \text { (averaged for all quadrats of } \\
\text { all habitat zones) }\end{array}$} \\
\hline
\end{tabular}

species excluded). The classification of the species into the 4 groups (according to Table 1) corresponded with clusters of juveniles and adults of species that could be distinguished using PCA (see Fig. 2). Juveniles and adults of seagrass residents and juveniles of nursery species were concentrated on the seagrass beds, while adults of nursery species were concentrated on the coral reef. Adults, generalists and reef residents were separated as 2 groups, although their juveniles showed no clear difference. Although density distributions others than the ones listed in Table 1 are theoretically possible, these did not occur and were thus not used as classification criteria.

The existence of possible interlinkages between fish communities of the 4 habitat zones can be derived from the density distributions of species on the gradient (such as the presence of an edge effect on species densities or species richness), and from relationships of density patterns between different species groups. To examine these possible interlinkages along the gradient, mean fish densities (pooling all size classes per quadrat), mean species richness, and mean total densities of each species group were compared between the 4 habitat zones. Differences between mean total fish density on the habitat zones were tested using 1-way ANOVA on $\log (x+1)$ transformed data. A Levene's test showed that variances were homogeneous after log-transformation. For mean species richness logtransformation was not needed (as determined with Levene's test). ANOVA was followed by a Gabriel's post-hoc test. Mean total fish densities between the 4 habitat zones of each species group (adults and juveniles pooled per quadrat) and mean total fish densities of juveniles and adults separately for each species group were compared using the following procedure: if variances were homogeneous (as determined with a Levene's test), a 1-way ANOVA was used on $\log (x+1)$ transformed data followed by a Gabriel's post-hoc 

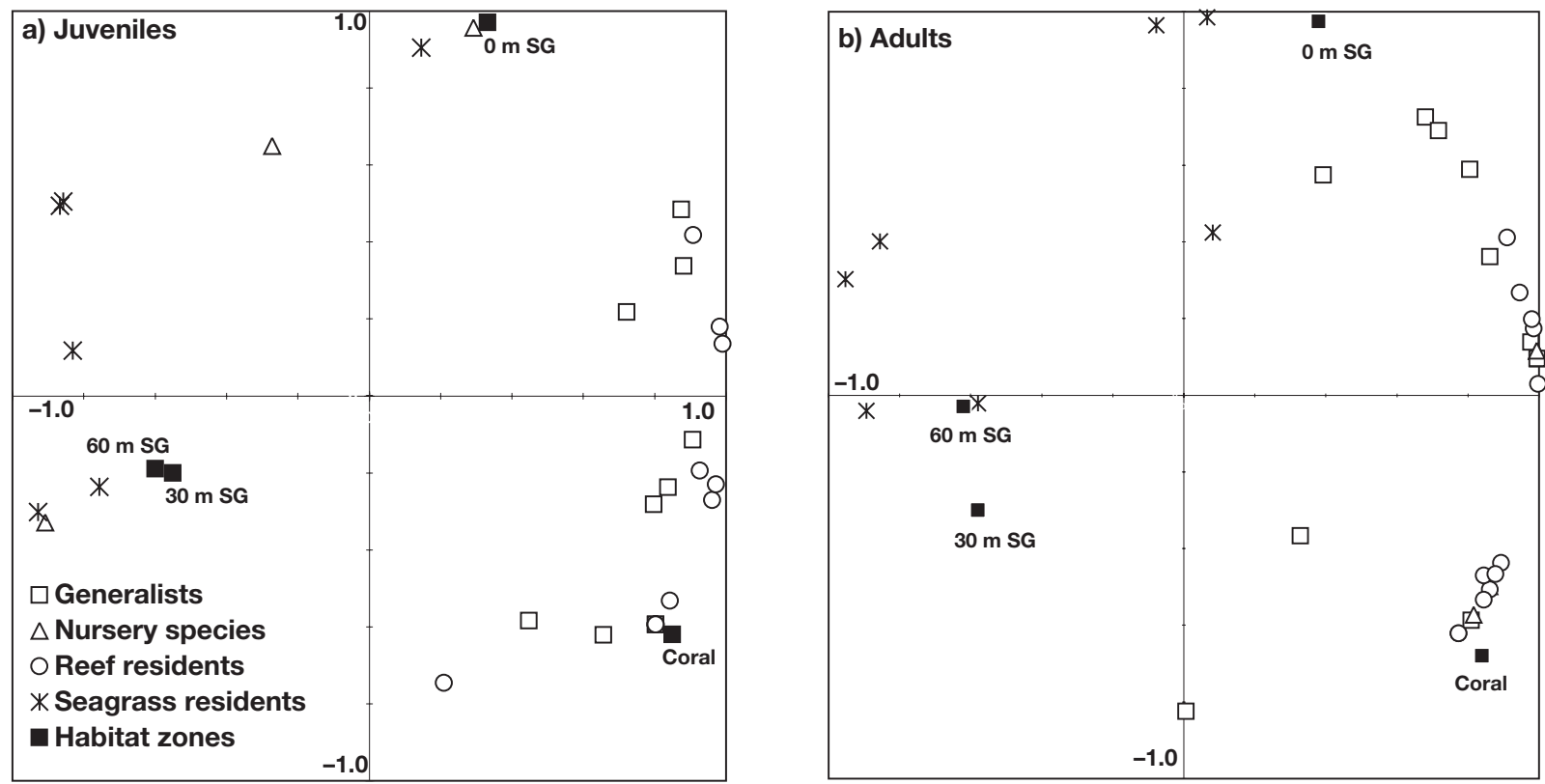

Fig 2. Principal component analysis (PCA) of mean densities of (a) juveniles and (b) adults of the observed species on the 4 habitat zones. Rare species (Tables 1 \& 2) are not included. Coral: coral reef zone; SG: seagrass zone

comparison. If variances were not homogeneous (not even after log-transformation), a Kruskal-Wallis test was used on non-transformed data followed by a Dunnett's T3 post-hoc comparison.

To detect possible interactions between species groups that occurred in high densities on the seagrass beds, correlations between mean fish densities of generalists and seagrass residents, between generalists and nursery species and between seagrass residents and nursery species along the seagrass gradient were examined by calculating non-parametric Spearman rank correlations. A Spearman rank correlation was also calculated between mean fish densities of juveniles and adults of nursery species along the seagrass gradient. All analyses were performed using SPSS version 11.5. PCA was performed using the Canoco 4.0 program (ter Braak \& Smilauer 1998). Species densities were $\log (x+1)$ transformed, scaling was focussed on inter-species distances, and species scores were divided by the standard deviation.

\section{RESULTS}

No significant differences in mean seagrass height $(F=1.08 ; \mathrm{p}=0.36 ; 1$-way ANOVA) or mean shoot density $(F=2.28 ; \mathrm{p}=0.11 ; 1$-way ANOVA $)$ were found between the 3 seagrass zones (Fig. 3). There was no significant correlation between mean seagrass height and mean shoot density (Spearman rank correlation coefficient $\left.\mathrm{r}_{\mathrm{s}}<0.01 ; \mathrm{p}=1.00\right)$.
In total, 48 species of the selected fish families were observed along the gradient (Table 2). Reef residents were represented by a greater number of species $(n=16)$ than generalists $(n=10)$ and seagrass residents $(n=7)$. Nursery species had the smallest number of species $(n=3)$. Twelve species occurred at very low densities.

Cluster analysis showed a great similarity between the coral reef and the $0 \mathrm{~m}$ seagrass zone, and between the 30 and $60 \mathrm{~m}$ seagrass zones (Fig. 4). Both mean total fish densities and mean total species richness

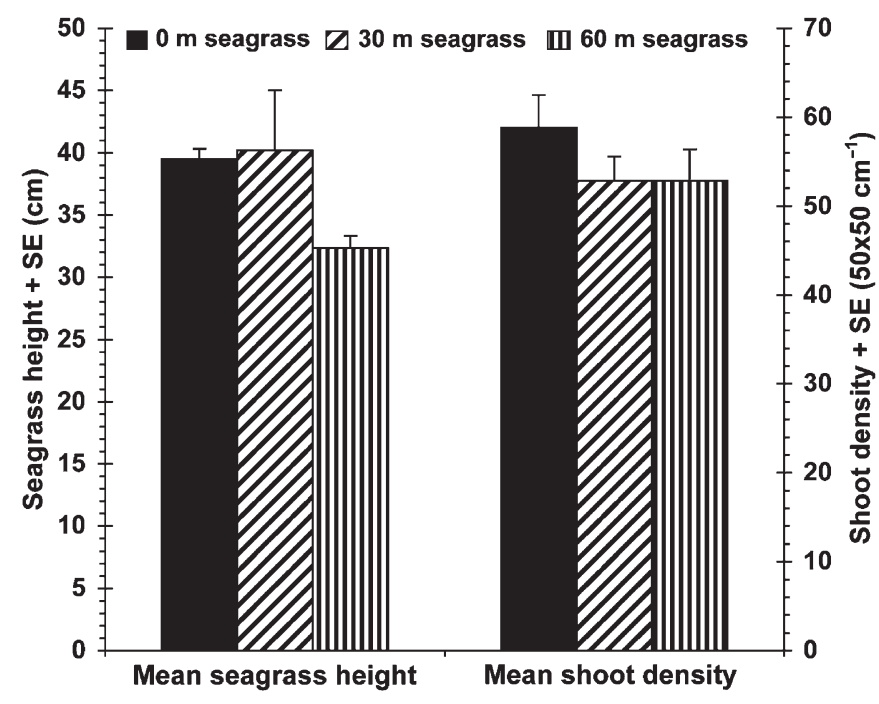

Fig 3. Mean shoot height and seagrass density in the 3 seagrass zones 
Table 2. Mean total density per species $\left(100 \mathrm{~m}^{-2}\right)$ and total number of species per species group (all quadrats pooled) in the 4 habitat zones. Rare species occurred with a total density $<0.25$ individuals $100 \mathrm{~m}^{-2}$ (pooling juveniles and adults, average for all quadrats of all habitat zones). Feeding guilds (based on Bouchon-Navaro 1986, Almeida et al. 1999, Meyers 1999, Froese \& Pauly 2003) were distinguished as: Hard $Z$ = hard zoobenthivores (species that predominantly feed on hard benthic prey such as molluscs, echinoderms and large crustaceans); $\mathrm{H}=$ herbivores; Soft $\mathrm{Z}=$ soft zoobenthivores (species that predominantly feed on soft benthic prey such as worms and small crustaceans); $\mathrm{S}=$ specialists (species with a specific food preference such as sponges or coral polyps); Z-P = zoobenthivores-piscivores. d: diurnali $\mathrm{n}$ : nocturnal

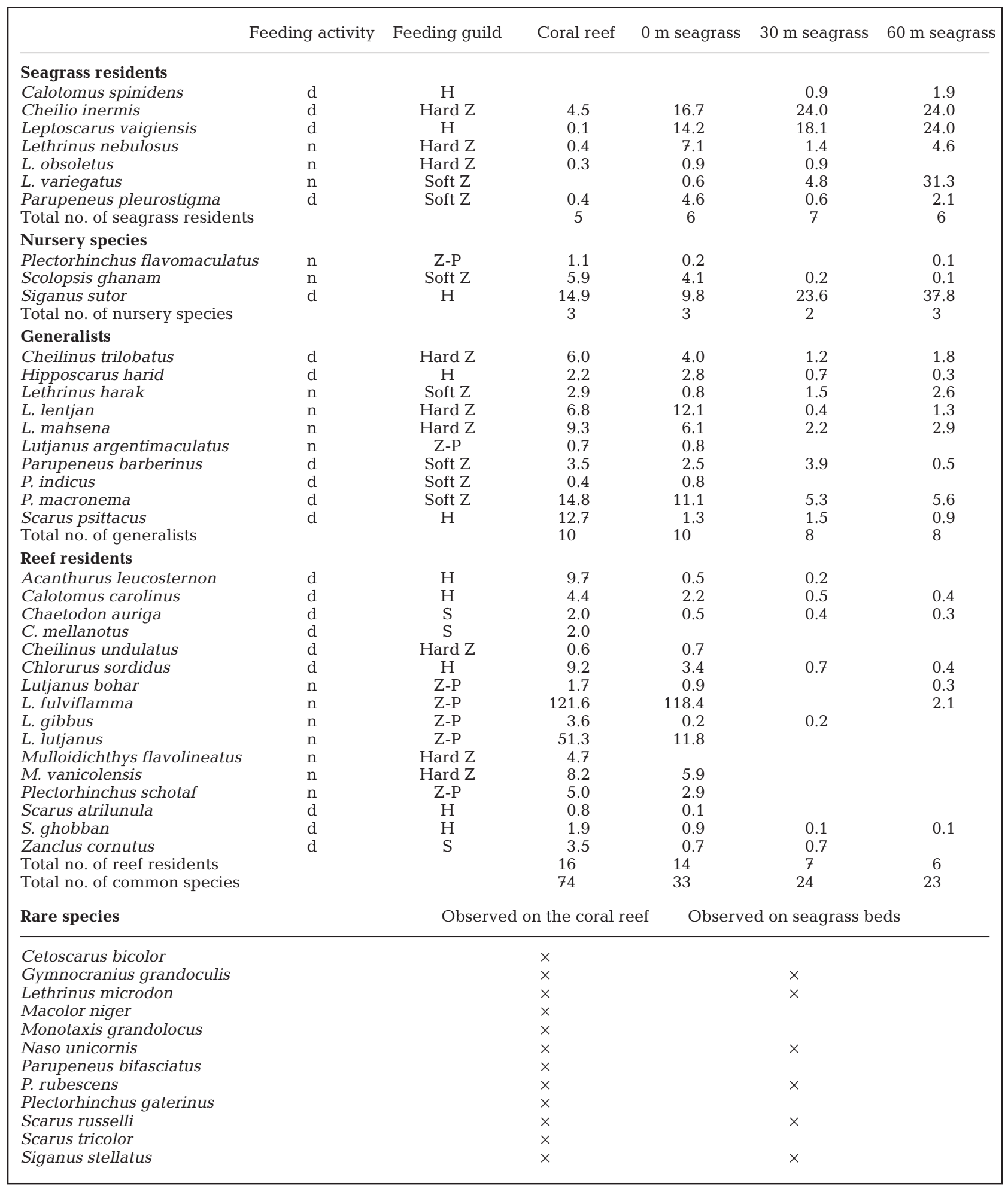


were significantly higher on the coral reef than on the 3 seagrass zones while no significant differences were observed between the 3 seagrass zones (Fig. 5, Table 3). The total number of observed species of seagrass residents, nursery species and generalists (all quadrats pooled) did not vary much between habitat types (Table 2). However, the total number of observed species of reef residents on the seagrass zones decreased from 14 species on the $0 \mathrm{~m}$ seagrass zone to 6 species on the $60 \mathrm{~m}$ seagrass zone (Table 2).

Mean total density of seagrass residents increased significantly with increasing distance from the coral reef, with the $60 \mathrm{~m}$ seagrass zone having the highest density (Fig. 6, Table 2, Table 3). Generalists showed a completely opposite pattern. Mean total densities of nursery species did not differ significantly between the coral reef, $0 \mathrm{~m}$ seagrass zone and $30 \mathrm{~m}$ seagrass zone, but the $60 \mathrm{~m}$ seagrass zone showed significantly higher densities than the coral reef and the $0 \mathrm{~m}$ seagrass zone. A significant negative correlation was present between the mean total fish densities of generalists and seagrass residents $\left(r_{\mathrm{s}}=-0.64, \mathrm{p}<0.010\right)$ and between generalists and nursery species $\left(r_{s}=-0.83, p<0.010\right)$ along the seagrass gradient. A significant positive correlation was observed between the mean total fish densities of seagrass residents and nursery species $\left(\mathrm{r}_{\mathrm{s}}=\right.$ $-0.96, p<0.010$ ). Densities of reef residents were high on the coral reef and in the $0 \mathrm{~m}$ seagrass zone but almost 0 in the 30 and $60 \mathrm{~m}$ seagrass zones (Fig. 6).

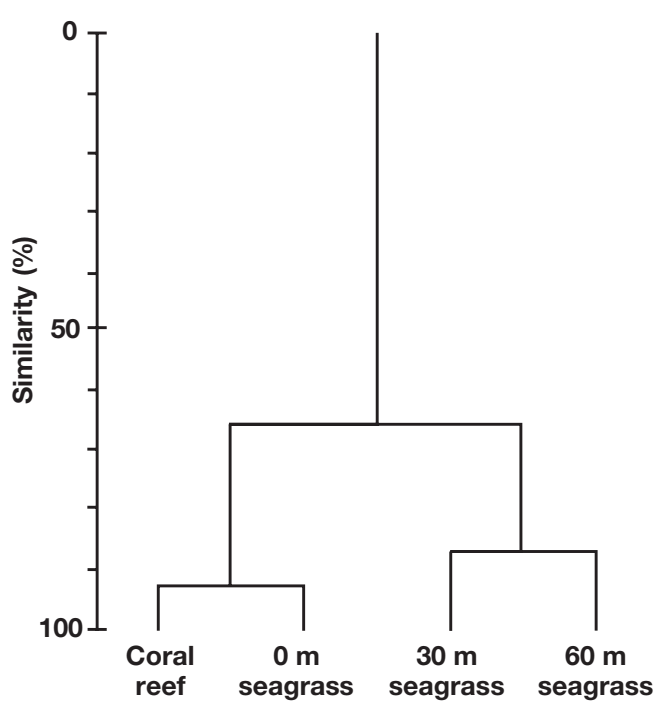

Fig. 4. Cluster analysis of the fish assemblage (48 species) from the 4 habitat zones in the coral reef-seagrass gradient. Euclidean distance and the group average linkage method were used as a clustering method, using log-transformed mean species densities $\left(100 \mathrm{~m}^{-2}\right)$

Densities of juvenile nursery species increased with increasing distance from the coral reef, whereas densities of adults decreased along this gradient (Fig. 7, Table 3). In contrast to the nursery species, both juveniles and adults of seagrass residents, generalists and reef residents showed similar distribution patterns on

Table 3. Overview of results (p-values) of statistical comparisons between mean fish density and mean species richness (Fig. 5), mean total fish densities per species group (Fig. 6) and mean total densities of juveniles and adults of species groups (Fig. 7) in the 4 habitat zones. K-W: Kruskal-Wallis test; NS: not significant ( $\mathrm{p}>0.05)$; Gabriel: Gabriel's pairwise test procedure; D T3: Dunnet's T3 post-hoc comparison. C: coral; 0,30,60: 0, 30, 60 m seagrass zone

\begin{tabular}{|c|c|c|c|c|c|c|c|c|c|}
\hline \multirow[t]{2}{*}{ Comparison } & \multicolumn{2}{|c|}{ Results ANOVA/K-W test } & \multicolumn{7}{|c|}{ Results post hoc comparisons of habitat zones } \\
\hline & Test & Result & Post-hoc test & $\mathrm{C}-0$ & $\mathrm{C}-30$ & $\mathrm{C}-60$ & $0-30$ & $0-60$ & $30-60$ \\
\hline Mean fish density & ANOVA & $<0.001$ & Gabriel & 0.001 & $<0.001$ & 0.014 & NS & NS & NS \\
\hline Mean species richness & ANOVA & $<0.001$ & Gabriel & $<0.001$ & $<0.001$ & $<0.001$ & NS & NS & NS \\
\hline \multicolumn{10}{|c|}{ Mean total fish density per species group } \\
\hline Seagrass residents & $\mathrm{K}-\mathrm{W}$ & $<0.001$ & D T3 & $<0.001$ & $<0.001$ & $<0.001$ & NS & 0.009 & 0.047 \\
\hline Nursery species & ANOVA & 0.006 & Gabriel & NS & NS & 0.016 & NS & 0.008 & NS \\
\hline Generalists & K-W & $<0.001$ & D T3 & NS & $<0.001$ & $<0.001$ & NS & NS & NS \\
\hline Reef residents & $\mathrm{K}-\mathrm{W}$ & $<0.001$ & D T3 & NS & $<0.001$ & $<0.001$ & NS & NS & NS \\
\hline \multicolumn{10}{|c|}{ Mean total densities juveniles and adults species groups } \\
\hline \multicolumn{10}{|l|}{ Seagrass residents } \\
\hline Juveniles & $\mathrm{K}-\mathrm{W}$ & $<0.001$ & D T3 & $<0.001$ & $<0.001$ & $<0.001$ & NS & NS & NS \\
\hline Adults & K-W & $<0.001$ & D T3 & 0.010 & 0.001 & $<0.001$ & NS & NS & NS \\
\hline \multicolumn{10}{|l|}{ Nursery species } \\
\hline Juveniles & ANOVA & $<0.001$ & Gabriel & NS & 0.016 & $<0.001$ & NS & $<0.001$ & NS \\
\hline Adults & $\mathrm{K}-\mathrm{W}$ & $<0.001$ & D T3 & NS & 0.033 & 0.027 & NS & NS & NS \\
\hline \multicolumn{10}{|l|}{ Generalists } \\
\hline Juveniles & $\mathrm{K}-\mathrm{W}$ & $<0.001$ & D T3 & NS & 0.001 & 0.024 & NS & NS & NS \\
\hline Adults & ANOVA & $<0.001$ & Gabriel & NS & $<0.001$ & $<0.001$ & NS & 0.012 & NS \\
\hline \multicolumn{10}{|l|}{ Reef residents } \\
\hline Juveniles & K-W & $<0.001$ & D T3 & NS & 0.004 & 0.003 & NS & NS & NS \\
\hline Adults & K-W & $<0.001$ & D T3 & NS & 0.002 & 0.003 & NS & NS & NS \\
\hline
\end{tabular}




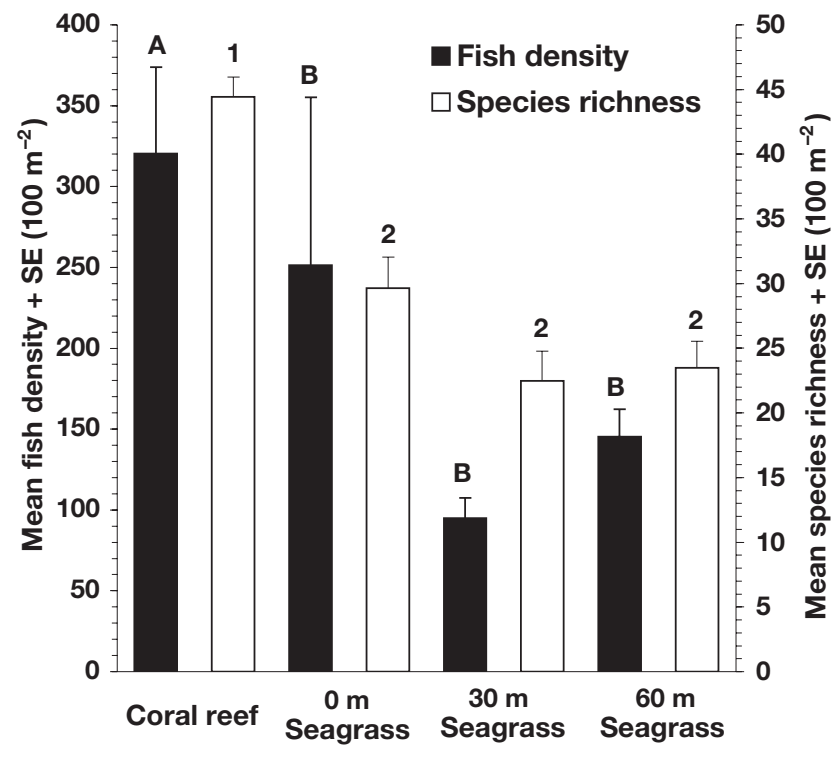

Fig. 5. Mean fish density and mean species richness of juveniles and adults (pooling all species) in the 4 habitat zones. Different numbers indicate significant differences (Table 3) for juveniles, while different letters indicate significant differences for adults. Juveniles were tested using 1-way ANOVA; adults were tested using a Kruskal-Wallis test

the gradient (Fig. 7, Table 3). A significant negative correlation was present between mean total adult densities and juvenile densities of nursery species along the seagrass gradient $\left(\mathrm{r}_{\mathrm{s}}=-0.88, \mathrm{p}<0.010\right)$.

At the level of feeding guilds, specialists consisted of 3 species of reef residents (see Table 2), and about $75 \%$ of the density of this feeding guild was observed on the coral reef (Fig. 8). Chaetodon mellanotus was exclusively observed on the reef while $C$. auriga and Zanclus cornutus also occurred in very low densities in the seagrass zones. Herbivores were more or less equally distributed over the habitat zones. However, this feeding guild was represented by species of all species groups with specific habitat preferences: seagrass residents in seagrass (Calotomus spinidens and Leptoscarus vaigiensis), reef residents on reef (Acanthurus leucosternon, Calotomus coralinus, Chlorurus sordidus, Scarus atrilunula and S. ghobban) and both nursery species (Siganus sutor) and generalists (Hipposcarus harid and Scarus psittacus) on seagrass and reef. Almost the complete density of the nocturnal zoobenthivores-piscivores (all observed Lutjanidae and Haemulidae species) was observed on the coral reef and the $0 \mathrm{~m}$ seagrass zone. The density distribution of nocturnal hard zoobenthivores showed a comparable pattern: almost $80 \%$ of the total density was observed on the coral reef and the $0 \mathrm{~m}$ seagrass zone. This feeding guild was represented by species of Lethrinidae that were classified as seagrass residents
(Lethrinus nebulosus and L. obsoletus) and generalists (L. lentjan and L. mahsena), and by 2 species of reef residents (Mulloidichthys flavolineatus and M. vanicolensis). Comparable to diurnal herbivores, diurnal hard zoobenthivores were almost equally distributed over all habitat zones. On species level, however, the species were separated by habitat use: Cheilio inermis on seagrass, Cheilinus undulatus on reef and C. trilobatus on both reef and seagrass. Nocturnal soft zoobenthivores showed a comparable pattern as that of nocturnal hard zoobenthivores, and $70 \%$ of the density was observed on the coral reef and the $0 \mathrm{~m}$ seagrass zone alone. One of the species of this guild was classified as a seagrass resident and did not occur on the coral reef (Lethrinus variegatus). The other 2 species occurred in higher densities on the coral reef (Scolopsis ghanam and Lethrinus harak). Almost $90 \%$ of the density of diurnal soft zoobenthivores was observed in the seagrass zones. This feeding guild consisted entirely of species of Mullidae that were classified as seagrass residents (Parupeneus pleurostigma) and generalists (Parupeneus barberinus, $P$. indicus and P. macronema).

\section{DISCUSSION}

The reef fish assemblages we observed along the coral reef-seagrass gradient show segregation as well as an interlinkage between the 2 habitat types, de-

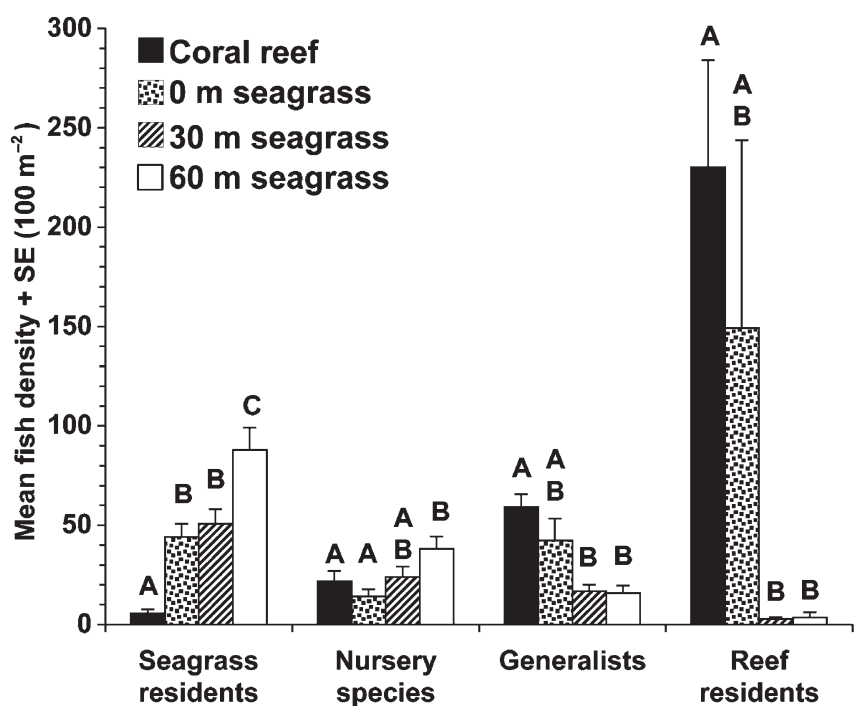

Fig. 6. Mean total fish densities (pooling all size classes) of seagrass residents, nursery species, generalists and reef residents in the 4 habitat zones. Different letters indicate significant differences (Table 3). Seagrass residents, generalists and reef residents were tested using a Kruskal-Wallis test, nursery species were tested using 1-way ANOVA 

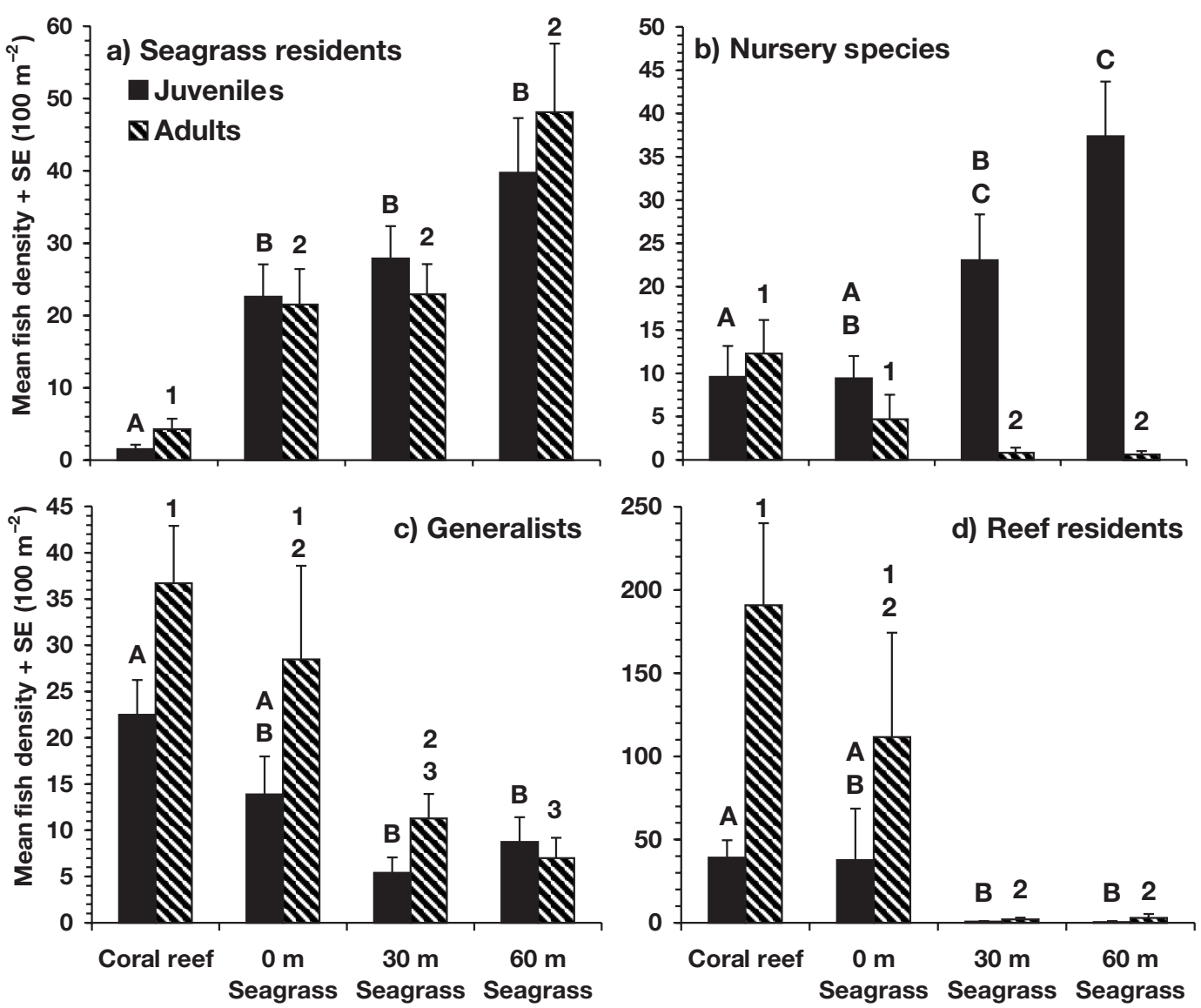

Fig. 7. Mean total densities of juveniles and adults of (a) seagrass residents, (b) nursery species, (c) generalists and (d) reef residents. Different letters show significant differences for juveniles, while different numbers show significant differences for adults (Table 3 )

pending on the fish species. The fish species can clearly be separated into 3 ecological groups: (1) reef fish species that are limited to the coral reef and its seagrass border zone (reef residents), (2) reef fish species that are limited to the seagrass beds (seagrass residents), and (3) reef fish species that use the coral reef as well as the seagrass habitat at various distances from the reef (generalists and nursery species). Species of group 2 are clearly limited to a single habitat and their species show little or no interlinkage between the coral reef and the seagrass bed. Species of group 1 and 3 , on the other hand, show an interlinkage between the coral reef and the seagrass bed and are found in both habitats.

The distribution of reef residents, seagrass residents, and generalists showed a gradual change between the 4 habitat zones. This distribution pattern may be explained by an edge effect. Reef residents are predominantly limited to the reef but do use the $0 \mathrm{~m}$ seagrass zone to some extent, after which their densities rapidly decrease on the other seagrass zones. Seagrass residents show the opposite pattern: these species show their highest density on the $60 \mathrm{~m}$ seagrass zone and a relatively high density on the seagrass bed near the reef edge, after which the density drops on the coral reef. Generalists showed decreasing densities from the coral reef to the $60 \mathrm{~m}$ seagrass zone but densities were comparable between the reef and the $0 \mathrm{~m}$ seagrass zone. Furthermore, similarity in fish assemblage was high between these 2 zones. These observations are in line with a transitional edge response described in terrestrial ecology where resources are concentrated in an optimal habitat while those in an adjacent lower quality habitat are supplementary (reviewed in Ries \& Sisk 2004). For the observed fish species resources are likely to be concentrated on either the seagrass beds (seagrass residents) or the coral reef (reef residents and generalists). However, the adjacent lower quality habitat (seagrass beds for reef residents and generalists, coral reef for seagrass residents) may provide supplementary resources, which may result in enhanced densities at the edge zone of this habitat. Most likely, this transitional edge response can therefore also be applied to marine ecosystems. 


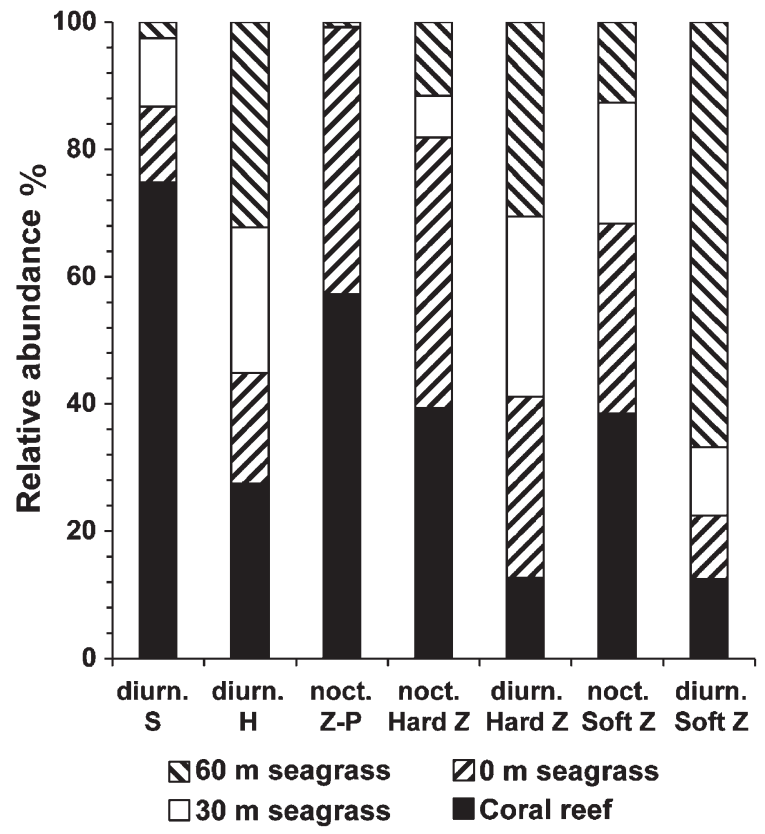

Fig. 8. Relative abundance of feeding guilds in the 4 habitat zones. Mean total densities of species (juveniles and adults pooled per quadrat) with a similar feeding ecology (listed in Table 2) are grouped into 1 feeding guild. Relative abundance of a feeding guild in the 4 habitat zones is expressed as percentage of the total fish density of the feeding guild. Feeding guild abbreviations as in Table 2. diurn.: diurnal feeders; noct.: nocturnal feeders

Also within the seagrass landscape a strong segregation exists for a part of the fish assemblage with respect to distance to the edge of the coral reef. Mean total fish density on the 3 seagrass zones was similar, which suggests that the available niches are optimally occupied by the selected species. However, the total density of seagrass residents and of juvenile nursery species increased with distance from the reef, while that of generalists and adults of nursery species decreased. Because the structure of the seagrass beds was uniform (1 seagrass species, no differences in seagrass height and density), these observations cannot be ascribed to differences in seagrass habitat complexity. Habitat segregation, possibly driven by competition (food, shelter) and/or predation mechanisms (e.g. Shulman 1985, Sweatman \& Robertson 1994, Clarke \& Tyler 2003, Nakamura \& Sano 2004b, Webster 2004) may be a more plausible explanation.

Feeding ecology may also partly explain the density distribution patterns of the observed species. Specialists showed a clear preference for the coral reef. Of these species, Chaetodon auriga and C. mellanotus primarily feed on alcyonarian and/or scleractinian corals (Bouchon-Navaro 1986). Zanclus cornutus primarily feeds on encrusting sponges (Myers 1991). These food sources are predominantly present on the coral reef and this most likely explains the preference of these 3 species for this habitat.

The 3 feeding guilds that were composed of nocturnal feeders (zoobenthivores-piscivores, hard zoobenthivores and soft zoobenthivores) were predominantly observed on the coral reef and $0 \mathrm{~m}$ seagrass zone. This may be explained by the fact that these species are inactive during the day, and that the coral reef and the edge of the coral reef ( $0 \mathrm{~m}$ seagrass zone) probably provide better shelter possibilities for these species than the $30 \mathrm{~m}$ and $60 \mathrm{~m}$ seagrass zones.

Although total densities of diurnal herbivores and diurnal hard zoobenthivores did not differ much between the habitat zones, individual species showed a clear habitat preference. Of the 3 observed Labridae species (hard zoobenthivores), Cheilio inermis was classified as a seagrass resident while Cheilinus undulatus was classified as a reef resident and C. trilobatus was a generalist. Several herbivores also showed these patterns: Leptoscarus vaigiensis and Calotomus spinidens were classified as seagrass residents, Hipposcarus harid was a generalist while Acanthurus leucosternon, Calotomus carolinus and Chlorurus sordidus were reef residents. This daytime habitat segregation on the level of species having a similar feeding ecology may increase optimal foraging and reduce competition. A similar explanation may be true for the difference between nocturnal and diurnal soft zoobenthivores. Almost $70 \%$ of the diurnal soft zoobenthivores were observed on the 30 and $60 \mathrm{~m}$ seagrass zones, while ca. $70 \%$ of the nocturnal zoobenthivores were observed on the coral reef and the $0 \mathrm{~m}$ seagrass zone. The diurnal species apparently select the seagrass bed as a feeding habitat during daytime, whereas the nocturnal species in the mean time shelter on the reef and its edge zone.

There was a significant negative correlation between juvenile and adult densities of nursery species along the seagrass gradient. Adults of nursery species showed the same distribution pattern as reef residents and generalists, whereas juveniles of these nursery species showed the same distribution pattern as seagrass residents. These observations indicate the existence of habitat segregation between life stages of individual species, and suggest direct interlinkages between the 2 habitats by means of possible ontogenetic shifts.

The results of the present study further show that the structure of the fish assemblage along the gradient studied is also the result of the spatial arrangement of the 2 habitat types. Because the coral reef directly borders the seagrass beds, the reef fish assemblages of the 2 habitats were able to interact. This results in distinct gradients in fish densities over the coral reef-seagrass landscape, something that is less likely to happen 
when there is some distance between the 2 habitats. This confirms the suggestion that the spatial arrangement of habitat types contributes to the structure of the associated fish species (Holbrook et al. 2002, Kendall et al. 2003, Grober-Dunsmore et al. 2004).

In conclusion, the present study shows the existence of habitat segregation between species or life stages of coral reef fishes along a continuous seagrass-coral reef gradient. Competition and feeding mechanisms, ontogenetic shifts, and the spatial arrangement of the habitats may be important factors in the process of habitat segregation.

Acknowledgements. This study was funded by the Nuffic through the ENVIRONS-MHO programme, by PADI Aware project and by Quo Vadis fund of the Radboud University Nijmegen (The Netherlands). We would like to thank the management and staff of the Institute of Marine Science in Zanzibar for the use of their facilities and for their support. We are also grateful to Simgeni Juma Simgeni and Abdalla Makame Mweleza for their help in the field. This is publication No. 361 of the Centre for Wetland Ecology.

\section{LITERATURE CITED}

Almeida AJ, Marques A, Saldanha L (1999). Some aspects of the biology of 3 fish species from the seagrass beds at Inhaca Island, Mozambique. Cybium 23:369-376

Appeldoorn RS, Recksiek CW, Hill RL, Pagan FE, Dennis GD (1997) Marine protected areas and reef fish movements: the role of habitat in controlling ontogenetic migration. Proc 8th Int Coral Reef Symp 2:1917-1922

Baelde P (1990) Differences in the structure of fish assemblages in Thalassia testudinum beds in Guadeloupe, French West Indies, and their ecological significance. Mar Biol 105:163-173

Beck MW, Heck KL, Able KW, Childers DL, Eggleston DB, Gillanders BM, Halpern B, Hays CG, Hoshino K, Minello TJ, Orth RJ, Sheridan PF, Weinstein MP (2001) The identification, conservation, and management of estuarine and marine nurseries for fish and invertebrates. Bioscience 51: 633-641

Blaber SJM (2000) Tropical estuarine fishes: ecology, exploitation and conservation. Blackwell Science, Oxford

Bouchon-Navaro Y (1986) Partitioning of food and space resources by Chaetodontid fishes on coral reefs. J Exp Mar Biol Ecol 103:21-40

Clarke RD, Tyler JC (2003) Differential space utilization by male and female spinyhead blennies, Acanthemblemaria spinosa (Teleostei: Chaenopsidae). Copeia 2:241-247

Cocheret de la Morinière E, Pollux BJA, Nagelkerken I, van der Velde G (2002) Post-settlement life cycle migration patterns and habitat preferences of coral reef fish that use seagrass and mangrove habitats as nurseries. Estuar Coast Shelf Sci 55:309-321

Eagle JV, Jones GP, McCormick MI (2001) A multi-scale study of the relationships between habitat use and the distribution and abundance patterns of 3 coral reef angelfishes (Pomacanthidae). Mar Ecol Prog Ser 241:253-265

Froese R, Pauly D (eds) (2003) Fish Base. World Wide Web electronic publication. www.fishbase.org

Grober-Dunsmore R, Frazer TK, Beets J, Funicelli N, Zwick
PD (2004) The significance of adjacent habitats on reef fish assemblage structure: are relationships detectable at a landscape scale? In: Proceedings of the 55th Gulf and Caribbean Fisheries Institute Meetings, Xel Ha, Mexico, 2002. Gulf and Caribbean Fisheries Institute, Fort Pierce, FL, p 713-734

Hay ME (1984) Patterns of fish and urchin grazing on Caribbean coral reefs: are previous results typical? Ecology 65:446-454

Holbrook SJ, Brooks AJ, Schmitt RJ (2002) Predictability of fish assemblages on coral patch reefs. Mar Freshw Res 53:181-188

Hyndes GA, Kendrick AJ, MacArthur LD, Stewart E (2003) Differences in the species- and size-composition of fish assemblages in 3 distinct seagrass habitats with differing plant and meadow structure. Mar Biol 142:1195-1206

Jiddawi NS, Stanley RD (1997) Fisheries stock assessment in the traditional fishery sector: the information needs. Canadian International Development Agency, Zanzibar

Kendall MS, Christensen JD, Hillis-Starr Z (2003) Multi-scale data used to analyze the spatial distribution of French grunts, Haemulon flavolineatum, relative to hard and soft bottom in a benthic landscape. Environ Biol Fish 66:19-26

Kochzius M (1997) Interrelation of ichthyofauna from a seagrass meadow and coral reef in the Philippines. In: Proceedings of the 5th Indo-Pacific Fisheries Conference, Nouméa, 1997. Antenne Museum-Ephe, Moorea, p 517-535

McAleece N (1997) BioDiversity Pro Beta 2. The Natural History Museum London/Scottish Association for Marine Science, London

Mumby PJ, Edwards AJ, Ernesto Arias-Gonzalez JE, Lindeman PG and 7 others (2004) Mangroves enhance the biomass of coral reef fish communities in the Caribbean. Nature 427:533-536

Munday PL, Jones GP, Caley MJ (2001) Interspecific competition and coexistence in a guild of coral-dwelling fishes. Ecology 82:2177-2189

Myers RF (1991) Micronesian reef fishes: a practical guide to the identification of the coral reef fishes of the tropical central and western Pacific, $2^{\text {th }}$ edn. Coral Graphics, Barrigada, Territory of Guam

Nagelkerken I, van der Velde G (2002) Do non-estuarine mangroves harbour higher densities of juvenile fish than adjacent shallow-water and coral reef habitats in Curaçao (Netherlands Antilles)? Mar Ecol Prog Ser 245:191-204

Nagelkerken I, Dorenbosch M, Verberk WCEP, Cocheret de la Morinière E, van der Velde G (2000a) Importance of shallow-water biotopes of a Caribbean bay for juvenile coral reef fishes: patterns in biotope association, community structure and spatial distribution. Mar Ecol Prog Ser 202:175-193

Nagelkerken I, van der Velde G, Gorissen MW, Meijer GJ, van't Hof T, den Hartog C (2000b) Importance of mangroves, seagrass beds and the shallow coral reef as a nursery for important coral reef fishes, using a visual census technique. Estuar Coast Shelf Sci 51:31-44

Nakamura Y, Sano M (2004a) Comparison between community structures of fishes in Enhalus acoroides- and Thalassia hemprichii-dominated seagrass beds on fringing coral reefs in the Ryuku Islands, Japan. Ichthyol Res 51:38-45

Nakamura Y, Sano M (2004b) Is there really lower predation risk for juvenile fishes in a seagrass bed compared with an adjacent coral area? Bull Mar Sci 74:477-482

Ogden JC, Buckman NS (1973) Movements, foraging groups, and diurnal migrations of the striped parrotfish Scarus croicensis Bloch (Scaridae). Ecology 54:589-596 
Ogden JC, Ehrlich PR (1977) The behaviour of heterotypic resting schools of juvenile grunts (Pomadasyidae). Mar Biol 42:273-280

Ogden JC, Brown RA, Salesky N (1973) Grazing by the echinoid Diadema antillarum Philippi: formation of halos around West Indian patch reefs. Science 182:715-717

Parrish JD (1989) Fish communities of interacting shallowwater habitats in tropical oceanic regions. Mar Ecol Prog Ser 58:143-160

Polunin NVC, Roberts CM (2004) Greater biomass and value of target coral-reef fishes in 2 small Caribbean marine reserves. Mar Ecol Prog Ser 100:167-176

Ries L, Sisk T (2004) A predictive model of edge effects. Ecology 85:2917-2926

Rooker JR, Dennis GD (1991) Dial, lunar and seasonal changes in a mangrove fish assemblage off southwestern Puerto Rico. Bull Mar Sci 49: 684-698

Sale P (2002) Coral reef fishes: Dynamics and diversity in a complex ecosystem. Academic Press, San Diego, CA

Shulman MJ (1985) Recruitment of coral reef fishes: effects of

Editorial responsibility: Otto Kinne (Editor-in-Chief),

Oldendorf/Luhe, Germany distribution of predators and shelter. Ecology 66:1056-1066 Sogard SM, Powell GVN, Holmquist JG (1987) Epibenthic fish communities on Florida Bay banks: relations with physical parameters and seagrass cover. Mar Ecol Prog Ser 40:25-39

Sweatman H, Robertson DR (1994) Grazing halos and predation on juvenile Caribbean surgeonfishes. Mar Ecol Prog Ser 111:1-6

ter Braak CJF, Smilauer P (1998) Reference manual and user's guide to Canoco for Windows: Software for canonical community ordination (version 4). Microcomputer power, Ithaca, NY

Watson RA, Quinn TJ (1997) Performance of transect and point count underwater visual census methods. Ecol Model 104:103-112

Webster MS (2004) Density dependence via intercohort competition in a coral-reef fish. Ecology 85:986-994

Weinstein MP, Heck KL (1979) Ichthyofauna of seagrass meadows along the Caribbean coast of Panama and the Gulf of Mexico: composition, structure and community ecology. Mar Biol 50:97-107

Submitted: October 20, 2004; Accepted: May 26, 2005

Proofs received from author(s): August 3, 2005 